\title{
Erbil Basin Groundwater Recharge Potential Zone Determination Using Fuzzy-Analytical Hierarchy Process (AHP)
}

Rahel Hamad ( $\square$ rahel.hamad@soran.edu.iq)

Soran University https://orcid.org/0000-0001-8848-2339

\section{Research Article}

Keywords: GIS, remote sensing, membership function, triangular fuzzy numbers

Posted Date: February 10th, 2022

DOI: https://doi.org/10.21203/rs.3.rs-1315621/v1

License: (c) (1) This work is licensed under a Creative Commons Attribution 4.0 International License.

Read Full License 


\section{Abstract}

Context: Severe water scarcity has occurred in the Erbil Basin (EB) due to climate change and mismanagement of water resources during the past three decades. Assessment of the potential area of groundwater recharge is extremely significant for the protection and management of groundwater systems and water quality.

Objectives: This research aims to use the Fuzzy-Analytic Hierarchy Process (F-AHP) technique to recharge the aquifer in places in the EB that are likely to be groundwater recharge areas in a geographic information system (GIS) environment.

Methods: GIS, remote sensing (RS), and F-AHP techniques were used to map the groundwater recharge potential zone in EB. Eight different geo-environmental factors were used to determine potential groundwater areas, namely; rainfall, lithology, geology, soil, slope, lineament density, land use/land cover (LULC), and Drainage density $\left(D_{d}\right)$. Then, the weights of the different thematic layers were assigned using a pairwise comparison matrix through the F-AHP.

Results: The total groundwater potential zone was shown to cover a very high area of 210.85 square kilometers $\left(\mathrm{km}^{2}\right)$, a high area of $188.94 \mathrm{~km}^{2}$, a moderate area of $573.06 \mathrm{~km}^{2}$, a low area of $1956.48 \mathrm{~km}^{2}$, and a very low area of $216.34 \mathrm{~km}^{2}$, according to the groundwater recharge potential zones (GWRPZs) map. As a result, nearly one-third of the areas investigated were found to have moderate-to-very high groundwater recharge potential.

Conclusions: This type of research can provide decision-makers and local governments with a broad perspective on current and future planning groundwater scarcity.

\section{Background}

Groundwater is a valuable resource and it is one of the important freshwater sources for domestic use, agriculture, and industry [1]. At present, nearly $34 \%$ of the world's water resources belong to groundwater [2]. Groundwater occurs in almost all landscapes [3], and all surface water features include streams, wetlands, lakes, reservoirs, and estuaries, which are usually hydraulically connected to groundwater [4]. Moreover, the natural and climatic environment of the landscape determines the presence of groundwater. For instance, a stream in a humid climate may receive groundwater influx, but a stream in an identical physiographic environment in a dry climate may lose water to groundwater [4]. Glacial or fluvial sediments, including basins, river valley alluvium, and fillings in the bedrock topography, are important groundwater reservoirs [5]. One of the prerequisites for sustainable groundwater management is groundwater recharge [6]. However, it is not always the amount of surface water that penetrates the moisture content of an aquifer [7].

Groundwater in Iraq, especially in the Erbil Basin has an important role in water supply, agriculture, health, and poverty eradication in rural areas [8]. It is usually recharged through precipitation and occasional 
snowmelt. However, in some topographic places, it can also be recharged by leakage from rivers, lakes, or canals [9]. The increasing demand for limited supplies in semi-arid and dry regions is reducing groundwater levels and leading to a critical state of groundwater recharge [10]. Generally, groundwater depletion has occurred all over the world as a result of overexploitation of groundwater [11] and particularly in the EB, where groundwater depletion has reached a point where it is nearly impossible to restore the groundwater table [8]. Therefore, the potential area's approach to groundwater recharge focuses specifically on promoting groundwater conservation, applying an appropriate scientific plan, regulating domestic and industrial water conservation practices, and leading to sustainable groundwater policies [12].

Many scientists investigated potential groundwater recharge zonation in semi-arid and arid regions using GIS, RS, and analytical hierarchical process techniques. For instance, India [13], United Arab Emirates [14], Tunisia [15], Egypt [16], Jordan [17], Israel [18], Syria [19], Turkey [20], and western Saudi Arabia [21].

The analytical hierarchy process (AHP)-based Multi Criteria Decision Making (MCDM) described by Saaty [22] is a very common method and it has been applied in widespread areas, including planning, choosing the best alternative, allocating resources, and resolving conflict [23]. This method calculates the weights of the criteria for selecting the most important criteria from among the alternative criteria and is therefore based on the order decision. Furthermore, MCDM is a sub-branch of operations research that reflects multiple criteria in decision-making environments [24]. Numerous previous investigations have used MCDM tools and applications to solve area problems such as the environment, energy, as well as sustainability, according $[13,24-26]$, in their literature review.

Overall, the GIS-based AHP, which is a traditional method, is a suitable tool for considering multiplecriteria decision analysis problems and simultaneously being applicable areas for using fuzzy set theory [27]. Fuzzy set theory was created to deal with the concept of partial truth values ranging from absolute right to absolute false [26]. From the late 1980s to the present, fuzzy-AHP methodologies have advanced rapidly, and countless applications based on F-AHP have been implemented and published in a variety of fields, including the environment, engineering, economics, and finance [28]. Moreover, the fuzzy-AHP is an extended method and was developed from the traditional AHP, which is used to solve MCDM problems [29]. The fuzzy method has been around for several decades and solves a lot of issues dealing with inaccurate and uncertain data. This method has some advantages over AHP and other MCDM in imprecise and uncertain contexts [30].

Furthermore, numbers are used instead of weight values in the fuzzy-AHP method to produce more realistic and accurate results and a more confident decision. In fact, the Fuzzy-AHP is a method that quantifies the AHP scale in the fuzzy triangle scale to reach priority [31,32]. To overcome inconsistencies that may arise at a certain level during the construction of a pairwise comparison matrix, Van Laarhoven and Pedrycz [33] proposed the F-AHP, which Chang [34] developed. The combination of GIS, RS, and FAHP has been verified to be a powerful tool in groundwater investigations [35]. Integrated GIS, RS, and FAHP techniques aim to categorize and prioritize a set of alternatives that best meet a set of criteria [36]. 
This technique was used to create groundwater potential map zones of the EB using meteorological, hydrological, and hydrogeological characteristics in the current study because it is a faster, more precise, and cost-effective way to detect the various factors important to the groundwater potential zone [27, 30, $35,37]$. In addition, valuable and rapid background information can be obtained from several thematic layers such as rainfall, lithology, geology, LULC, slope, NDVI, DEM, drainage density, lineament density, and others through those factors that control the occurrence and movement of groundwater [37].

The main goal of this research is to use AHP-coupled MCDA, GIS, and RS, as well as Fuzzy-AHP approaches, to delineate groundwater potential zones for sustainable development and management.

\subsection{Groundwater Hydrology in Erbil Basin}

EB covers an area of $3145 \mathrm{~km}^{2}$, with a length of $75 \mathrm{~km}$ and a maximum width of $55 \mathrm{~km}$. According to AlAnsari, Essaid [38], the depth of EB wells in the 1980s was between 5 and 30 meters. In 1996, the depth of wells was increased by approximately 150 to 200 meters, stated Kznee [39], but by 2015, it had risen to between 300 and 600 meters. As a result, there is a significant and catastrophic depletion of groundwater, which is the worst-case scenario for the Erbil basin's aquifer system. However, since 2011, on the Greater Zab River, water treatment plants have been built to provide drinking water to a large portion of Erbil city. Accordingly, the city of Erbil's water supply relies on $45 \%$ of the groundwater through wells and surface water for $55 \%$ of the water treatment plant units through its needs [40].

The Greater Zab River surrounds the EB on the northwest and the Lesser Zab River on the southeast. They are the largest tributaries of the Tigris River and the region of Iraqi Kurdistan's primary source of surface water [41]. Moreover, a semicircular depression that represents Erbil plain separates the Pirmam anticline to the northeast and the Kirkuk structure to the southwest, Figure 1. In general, Habib, Al-Saigh [42] divided the EB into three secondary sub-basins: the northern Kapran sub-basin, the central sub-basin, and the southern Bash Tepa sub-basin.

Normally, the recharge zones are determined by the geological, hydrogeological, and topographic characteristics of the area. Moreover, the spatial distribution and extensions of hydrogeological components in terms of aquifers and aquitards, as well as their hydrological characteristics, are governed by geological, structural, and lithological conditions [43]. The presence of thick terrigenous sediments in the middle of the Erbil plain, which reach up to $850 \mathrm{~m}$ in thickness, makes the EB one of the most important promising areas for groundwater resources in the low folded zone [44].

From the hydrogeological point of view, the EB is a part of the low folded zone, which is strongly influenced by its geological setting. The majority of the study areas are characterized by a plain divided by river valleys and controlled by a broad synclinal structure with linear hilly belts and anticlines. Geologically, this area is mainly covered by the conglomerate aquifers in the Quaternary and Pliocene within the formation of Bai Hassan, and some part covers by sandstone aquifers within the Injana (Miocene-Pliocene) and Muqdadiyah (Pliocene) formations [43]. Furthermore, there are numerous hills, which are usually folded strata and extend in a parallel pattern from NW to SE. These hills range in 
elevation from 200 meters in the south to 500 meters in the northeast. Typically, these hills are narrow, with extremely wide plains in between [41].

The amount of recharge of the aquifer storage in the recharge area, as well as the velocity of the porous media in the region, determine the increase in groundwater level [40]. The major groundwater basins are formed by broad synclinal valleys that are filled with sedimentary sequences ranging in age from Late Miocene to Recent. The main groundwater divides, especially in the elevated parts of the Low Folded Zone, where groundwater discharge occurs along streams and rivers, coincide with surface water flow. The potential for groundwater development along these streams and rivers could be significant [44].

\subsection{Study area}

This research is being carried out in the EB, which includes Erbil City, the capital of Iraq's Kurdistan Region (KRI). The geographical setting for the EB is between latitudes $35^{\circ} 46^{\prime} \mathrm{N}$ and $36^{\circ} 34^{\prime} \mathrm{N}$ and longitudes $43^{\circ}$ $34^{\prime}$ and $44^{\circ} 19^{\prime} \mathrm{E}$. The GZR is the most important branch of the Tigris River, which springs from southeastern Turkey at an altitude of more than 4,000 $\mathrm{m}$ above sea level and flows into northern Iraq [45]. The Lower Zab River, on the other hand, extends from northeast Iran to Iraq and is located south of the GZ. The normal temperature ranges from $1^{\circ} \mathrm{C}$ in December-February to $44^{\circ} \mathrm{C}$ in July-August. The elevation ranges between 171 and 1091 meters above sea level and consists of numerous hills and flat terrains as the most prominent morphological features of semi-arid climatic conditions with the potential for direct run-off, Figure 1. This area was chosen because it contains the largest groundwater reservoir in the Erbil Governorate and is one of the most important groundwater aquifers in the Middle East, with conglomerates, sandstones, sand, and gravel forming the majority of the aquifers [41].

\section{Materials \& Method}

\subsection{Data set}

For this study area, USGS Earth Explorer (https://earthexplorer.usgs.gov/) was used to download Landsat 8 OLI to prepare the LULC map, SRTM-DEM to obtain average slope, drainage network information, and drainage density map. The geological and lithological maps were obtained from the Directorate of Surveying of Iraq, while the soil map was gained and digitized from Iraq's exploratory soil map from 1960. Table 1, summarizes the details of all used data and output layers. This study combined GIS, RS, and fuzzy-AHP approaches to identify and assess groundwater recharge potential zones. Eight influencing factors were selected, namely; rainfall, geology, lithology, slope, drainage density, lineament density, LULC, and soil. Different tools were used to create various thematic maps, which were then converted to raster format with a spatial resolution of 30 meters and projected in UTM Projection, Zone $38 \mathrm{~N}$, and WGS 84 Datum. The main factors that influence groundwater recharge potential in the study area are listed in Table 2. 
Table 1

Details of the different data sets used in preparing the GWPM

\begin{tabular}{|c|c|c|c|c|c|}
\hline $\begin{array}{l}\text { Data } \\
\text { type }\end{array}$ & Detail of data & $\begin{array}{l}\text { Available } \\
\text { format }\end{array}$ & Extracted layer & Generated layer & $\begin{array}{l}\text { GIS } \\
\text { data } \\
\text { type }\end{array}$ \\
\hline $\begin{array}{l}\text { Satellite } \\
\text { imagery }\end{array}$ & $\begin{array}{l}\text { Landsat } 8 \\
\text { Acquis. date } \\
28.08 .2021\end{array}$ & ENVI 5.3 & LULC & LULC & Raster \\
\hline $\begin{array}{l}\text { SRTM- } \\
\text { DEM }\end{array}$ & $2014-30 m$ & TIFF & $\begin{array}{l}\text { Contour, } \\
\text { Elevation } \\
\text { Drainage } \\
\text { network }\end{array}$ & $\begin{array}{l}\text { Slope, Hillshade, } \\
\text { Drainage Density, } \\
\text { Lineament Density }\end{array}$ & $\begin{array}{l}\text { Raster } \\
\text { Raster } \\
\text { Raster }\end{array}$ \\
\hline $\begin{array}{l}\text { Geology } \\
\& \\
\text { Lithology }\end{array}$ & Unit types & $\begin{array}{l}\text { ESRI } \\
\text { shapefile } \\
\text { ESRI } \\
\text { shapefile }\end{array}$ & $\begin{array}{l}\text { Geology } \\
\text { Lithology }\end{array}$ & $\begin{array}{l}\text { Geology } \\
\text { Lithology }\end{array}$ & $\begin{array}{l}\text { Raster } \\
\text { Raster }\end{array}$ \\
\hline Soil map & Unit types & $\begin{array}{l}\text { ESRI } \\
\text { shapefile }\end{array}$ & Soil types & Soil types & Raster \\
\hline Rainfall & 2001-2020 & $\begin{array}{l}\text { ESRI } \\
\text { shapefile }\end{array}$ & Rainfall map & Rainfall map & Raster \\
\hline $\begin{array}{l}\text { Depth to } \\
\text { water } \\
\text { level }\end{array}$ & 2019 & $\begin{array}{l}\text { Central } \\
\text { Ground } \\
\text { Water } \\
\text { Board }\end{array}$ & point & point & point \\
\hline
\end{tabular}

Table 2

The factors affecting groundwater recharge potential are listed.

\begin{tabular}{|ll|}
\hline Factors & Basis of categorization \\
\hline Rainfall & The average annual precipitation \\
\hline Geology & Rock formation type \\
\hline Lithology & Lithology Rock-type, weathering character, joints, and fractures \\
\hline LULC & Type, areal extent, associated vegetation \\
\hline Lineament & Lineament-density value \\
\hline Drainage & Drainage density value \\
\hline Soil & Type of soil \\
\hline Slope & Slope gradient \\
\hline
\end{tabular}


Table 3. Assigned ranks for different features of eight conditioning factor for groundwater potential

Criteria

Rainfall

GEOLOGY

DD

LULC

Lineament

Slope

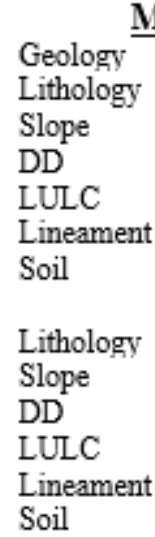

Slope

$\mathrm{DD}$

LULC

Lineament

Soil

DD

LULC

Lineament

Soil

LULC

Lineament

Soil

Soil

Soil mapping.

More important?

Rainfall

Rainfall

Rainfall

Rainfall

Rainfall

Rainfall

Rainfall

Scale 1-9

Geology

Geology

Geology

Geology

Geology

Geology

Lithology

Lithology

Lithology

Lithology

Lithology

Slope

Slope

Slope

Slope

DD

DD

DD

LULC

LULC

Lineament

3

For the computation of weights of different features and thematic layers, Saaty's multi-criteria evaluation, which is the most applicable approach for solving problems, was used. The weighted index overlay method was used to combine all of the thematic layers. The data layers were then given weights to reflect their relative importance [22].

In general, in order to comprehend the concept of overlay analysis, two terms must be understood, "influence" and "scale value". "Influence" refers to a layer's overall importance, which is measured in percentages for each thematic layer, while the "scale value" is based on the importance of the features in the layer [46]. The least important value is one (1), and the most important value is five (5). In AHP, the percentage influence will compare each factor pairwise. In the current study, for example, AHP will compare rainfall to the other seven thematic layers, as well as other factors. Then, on a scale of 1 to 9 , a value will be assigned. Nine (9) means "extremely important," five (5) means "strongly important," and one (1) means "equally important.", Table 3 [22].

\subsection{Preparation and computation of the thematic layers}

Rainfall data were collected from various rain gauging stations throughout the study area for the twenty years 2001-2020 and summed up into an annual average. Average annual precipitation was calculated 
and projected to generate a rainfall thematic layer using the IDW interpolation method. For overlaying purposes, the rainfall map was classified into five classes. The geological map was produced by the general directorate of the survey. The geological map of the study area was categorized into five classes, namely: polygenetic and slope deposits, Bai Hassan, Fatha, Injana, and Mukdadyah. In terms of the surficial lithology map, it has been prepared using the geological map from the general directorate of the survey. The EB is covered most by Quaternary sediments, which are considered most important for groundwater storage due to their high hydraulic conductivity, followed by sandstone, silty sandstone, and silty/sandy mudstone [47]. Moreover, Landsat 8 operation land imager for 2021 was downloaded from the Earth Explorer USGS website and processed in ENVI 5.3 and ArcGIS 10.7.1 to produce a land use/land cover map. Bands 1, 2, 3, 4, 5, 6, and 7 were composited and generated the LULC map. Henceforward, the study area was classified into five classes namely, barren land, built-up, cropland, rangeland, and water bodies. After digitizing the training samples, the signature file was developed for supervised mapping through a maximum likelihood classifier. On the other hand, the surficial lineament density was produced using hill shade under raster surface, arc toolbox in ArcGIS of Landsat $8 \mathrm{OLI}$. A group of polylines was defined and produced lineament in ArcGIS 10.7.1. Drainage density $\left(D_{d}\right)$ as a significant factor in groundwater exploration was also prepared by dividing the total length of streams in the area. The slope layer was extracted from DEM at $30 \mathrm{~m}$ and divided into five classes. Slope affects the amount of water availability for infiltration due to effects on local soil water balances [48]. Lastly, the digital soil map produced by FAO/UNESCO, in 1995 was prepared and used in this study.

\subsection{Research Method and Procedure}

\subsubsection{Fuzzy-AHP}

In the "fuzzy set" theory, there is a very precise and clear boundary to indicate if an entity belongs to a well-defined "set" of entities, and there is a sharp, crisp, and unambiguous distinction between a member and a nonmember of any well-defined "set" of entities. To put it another way, when someone asks, "Is this entity a member of that set?" Either "yes" or "no" is the answer. This holds true in both deterministic and stochastic situations. "What is the probability of this entity being a member of that set?" is a question that can be asked in probability and statistics. Thus, the fuzzy set theory will be seen to be a natural extension of the classical set theory, as well as a rigorous mathematical concept [49]. The concept of fuzzy sets is a conceptual and mathematical framework for investigating imprecise and ambiguous phenomena [50], and it enables the individual to operate in uncertain and ambiguous situations and to solve poorly posed problems or problems with incomplete information [51].

Furthermore, the process of the 'fuzzification', is the transformation of a crisp set into a fuzzy set or a fuzzy set into a fuzzier set. This operation essentially converts precise, crisp input values into linguistic variables, which are then converted into membership functions [52]. De-fuzzification, on the other hand, is defined as the process of converting a fuzzy member into a crisp member or reducing a fuzzy set to a crisp set [53]. 
Generally, this judgment should have been supported by experience in the study area. A verbal judgment should follow certain guidelines, such as consistency ratio (CR), to be acceptable. Moreover, if the CR consistency ratio is less than 0.05 for the $3 \times 3$ matrix, 0.09 for the $4 \times 4$ matrix, and 0.1 for larger matrices, the pairwise comparison matrix is said to be consistent [54]. The CR for all elements in the current study was less than 0.1 , indicating that the matrix and element evaluations were consistent.

The pair-wise comparison matrix was generated using a denotative 9-point scale, with 1, 3, 5, 7, and 9 representing important, moderately important, strongly important, extremely strongly important, and extremely strongly important, respectively, Table 4.

Table 4

Effects and rates of factors affecting groundwater potentiality calculations [22]

\begin{tabular}{|lll|}
\hline Definition & $\begin{array}{l}\text { Relative } \\
\text { importance }\end{array}$ & $\begin{array}{l}\text { Triangular Fuzzy } \\
\text { Number }\end{array}$ \\
\hline Equal importance & $\mathbf{1}$ & $(1,1,1)$ \\
\hline Middle value between 1 and 3 & $\mathbf{3}$ & $(2,3,4)$ \\
\hline Strong & $\mathbf{5}$ & $(4,5,6)$ \\
\hline Very strong & $\mathbf{7}$ & $(6,7,8)$ \\
\hline Extremely strong & $\mathbf{9}$ & $(9,9,9)$ \\
\hline Intermediate Values & $\mathbf{2}$ & $(1,2,3)$ \\
$2,4,6,8$ can be used to express the intermediate & $\mathbf{4}$ & $(3,4,5)$ \\
\hline value & $\mathbf{6}$ & $(5,6,7)$ \\
\hline
\end{tabular}

Fuzzy-AHP is a dominant approach and has been used by many scientists to determine the potential area of groundwater [29]. In this work, the fuzzy triangular number technique was used to represent a pair-wise comparison of GWRPZ selection. The fuzzy-AHP method was considered in this study since the traditional AHP is not able to deal with the inaccurate nature of the linguistic calculation while making pairwise comparisons of the criteria [37].

\subsubsection{Triangular fuzzy numbers}

The fuzzy triangular number $\mu(\mathrm{x})$ can be depicted as in Figure 2 , which is easily presented in the formula 1.

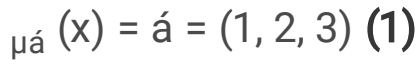


The fuzzy numbers 1,2 , and 3 represent the lower $(I)$, middle $(m)$, and upper $(u)$ numbers from the triangular membership function, respectively, whereas the function value $\mu a ́(x)$ is referred to as the grade of membership of $(x)$ in á (x-axis). The fuzzing values will be used to replace the single and intermediate numbers in the fuzzy scale importance number $(I, m, u)$. Where $\mathrm{I} \leqq \mathrm{m} \leqq \mathrm{u}$, simultaneously, $\mathrm{I}=\mathrm{m}=\mathrm{u}$, and it is a non-fuzzy number by convention.

Furthermore, for two triangular fuzzy numbers $A_{1}=\left(I_{1}, m_{1}, u_{1}\right)$ and $A_{2}=\left(I_{2}, m_{2}, u_{2}\right)$, the main operational laws are expressed as formula $\mathbf{2}$ :

\section{$\AA 1 \oplus \AA 2=(11+\mid 2, \mathrm{~m} 1+\mathrm{m} 2, \mathrm{u} 1+\mathrm{u} 2)(2)$}

Formula $\mathbf{3}$ will be used to convert the crisply valued into fuzzy numbers in order to obtain the fuzzy pairwise metrics.

$a^{-1}=(l, m, u)^{-1}=(1 / u, 1 / m, 1 / l)(3)$

Fuzzy-AHP was proposed by Buckley (1985), in which calculating weights through the geometric mean will be applied, by multiplying two fuzzy numbers, Formula $\mathbf{4}$ multiplied fuzzy number equation.

$A 1 \otimes A 2=\left(l_{1}, m_{1}, u_{1}\right) \otimes\left(l_{2}, m_{2}, u_{2}\right)=\left(l_{1}^{*}{ }_{2}, m_{1} * m_{2}, u_{1} * u_{2}\right)(4)$

Then, the fuzzy geometric mean and the procedures for determining the weights of the criteria can be calculated by Buckley (1985) as formula $\mathbf{5}$ :

$w^{\sim} \sim_{i}=r^{\sim i} \otimes\left(r_{1} \oplus r_{2} \oplus \ldots \oplus r_{n}\right)^{-1}(5)$

By implementing formula 6 for adding two fuzzy numbers, the reciprocal of the sum will be calculated.

\section{$A 1 \oplus \AA 2=((11+\mid 2, \mathrm{~m} 1+\mathrm{m} 2, \mathrm{u} 1+\mathrm{u} 2)(6)$}

Finally, the de-fuzzification method through applying the center of area (COA) method, formula 7, will be used in order to obtain the fuzzy weights. The end process is obtaining the total normalized weight, which is 1 .

$(\mathrm{COA})=(1+m+u / 3)(7)$

The final step is to conduct a test to determine the extent of consistency associated with the comparison matrix using the consistency ratio (CR) formula 8.

\section{Consistency ratio (CR) = Cl / $\mathrm{RI}(8)$ \\ 2.3.3 Empirical illustration}

The AHP model has been developed through four stages; weight assignment, development of a pairwise comparison matrix, a consistency ratio (CR) check for fuzzy pairwise comparison, and determining 
weight normalization. Thus, the next step will be to replace the scale of relative importance for all numbers after creating the pairwise comparison matrix, Table 5 , and the scale of relative importance with the crispy values, Table 6.

Table 5

Pairwise comparison matrix for drainage density of the study area

\begin{tabular}{|llllll|}
\hline Matrix & $\mathbf{0 - 0 . 8 7}$ & $\mathbf{0 . 8 7} \mathbf{- 1 . 7 5}$ & $\mathbf{1 . 7 5 - 2 . 6 2}$ & $\mathbf{2 . 6 2 - 3 . 5 0}$ & $\mathbf{3 . 5 0} \mathbf{- 4 . 3 8}$ \\
\hline $0-0.87$ & 1 & 3 & 5 & 7 & 9 \\
\hline $0.87-1.75$ & $1 / 3$ & 1 & 3 & 5 & 7 \\
$1.75-2.62$ & $1 / 5$ & $1 / 3$ & 1 & 3 & 5 \\
\hline $2.62-3.50$ & $1 / 7$ & $1 / 5$ & $1 / 3$ & 1 & 3 \\
\hline $3.50-4.38$ & $1 / 9$ & $1 / 7$ & $1 / 5$ & $1 / 3$ & 1 \\
\hline
\end{tabular}

Table 6

displays the pairwise comparisons scale used in the Fuzzy-AHP method (Tseng et al. 2008).

\begin{tabular}{|lll|}
\hline Linguistic scale for the importance & Triangular fuzzy scale Triangular & fuzzy reciprocal scale \\
\hline Just equal & $(1,1,1)$ & $(1,1,1)$ \\
\hline Equally important (EI) & $(1 / 2,1,3 / 2)$ & $(2 / 3,1,2)$ \\
\hline Weakly more important (WMI) & $(1,3 / 2,2)$ & $(1 / 2,2 / 3,1)$ \\
\hline Strongly more important (SMI) & $(3 / 2,2,5 / 2)$ & $(2 / 5,1 / 2,2 / 3)$ \\
\hline Very strongly more important (VSMI) & $(2,5 / 2,3)$ & $(1 / 3,2 / 5,1 / 2)$ \\
\hline Absolutely more important (AMI) & $(5 / 2,3,7 / 2)$ & $(2 / 7,1 / 3,2 / 5)$ \\
\hline
\end{tabular}


Table 7

A fuzzified pairwise comparison matrix assigned a fuzzy number of drainage densities in the study area.

\begin{tabular}{|c|c|c|c|c|c|c|}
\hline Matrix & $0-0.87$ & $0.87-1.75$ & $1.75-2.62$ & $2.62-3.50$ & $\begin{array}{l}3.50- \\
4.38\end{array}$ & $\begin{array}{l}\text { Fuzzy geometric mean } \\
\text { value } r_{i}\end{array}$ \\
\hline $0-0.87$ & $(1,1,1)$ & $(2,3,4)$ & $(4,5,6)$ & $(6,7,8)$ & $(9,9,9)$ & $\begin{array}{l}(3.3658,3.9363 \\
4.4413)\end{array}$ \\
\hline $\begin{array}{l}0.87- \\
1.75\end{array}$ & $\begin{array}{l}(1 / 4,1 / 3 \\
1 / 2)\end{array}$ & $(1,1,1$ & $(2,3,4)$ & $(4,5,6)$ & $(6,7,8)$ & $\begin{array}{l}(1.6437,2.0321, \\
2.4914)\end{array}$ \\
\hline $\begin{array}{l}1.75- \\
2.62\end{array}$ & $\begin{array}{l}(1 / 6,1 / 5 \\
1 / 4)\end{array}$ & $\begin{array}{l}(1 / 4,1 / 3 \\
1 / 2)\end{array}$ & $(1,1,1)$ & $(2,3,4)$ & $(4,5,6)$ & $\begin{array}{l}(0.7962,0.9979 \\
1.2457)\end{array}$ \\
\hline $\begin{array}{l}2.62- \\
3.50\end{array}$ & $\begin{array}{l}(1 / 8,1 / 7 \\
1 / 6)\end{array}$ & $\begin{array}{l}(1 / 6,1 / 5, \\
1 / 4)\end{array}$ & $\begin{array}{l}(1 / 4,1 / 3 \\
1 / 2)\end{array}$ & $(1,1,1)$ & $(2,3,4)$ & $\begin{array}{l}(0.3981,0.5306 \\
0.6034)\end{array}$ \\
\hline $\begin{array}{l}3.50- \\
4.38\end{array}$ & $\begin{array}{l}(1 / 9,1 / 9 \\
1 / 9)\end{array}$ & $\begin{array}{l}(1 / 8,1 / 7 \\
1 / 6)\end{array}$ & $\begin{array}{l}(1 / 6,1 / 5, \\
1 / 4)\end{array}$ & $\begin{array}{l}(1 / 4,1 / 3 \\
1 / 2)\end{array}$ & $(1,1,1)$ & $\begin{array}{l}(0.2228,0.2619, \\
0.2941)\end{array}$ \\
\hline
\end{tabular}

Thus, the fuzzification, formula 2 , is replacing the scale of relative importance like $(1,3,5,7$, and 9$)$ with fuzzy numbers. On the other hand, the fuzzy reciprocal numbers $(1 / 3,1 / 5,1 / 7$, and $1 / 9)$ in Table 5 will be converted to the fuzzy number by using formula $\mathbf{3}$ as presented in Table 6 . Then, the geometric mean based on Buckley [55] will calculate the weights. Consequently, the fuzzy geometric mean value will be calculated using the formula $\mathbf{4}$ to multiply two fuzzy numbers. As a result of taking the fifth root, the lower, middle, upper points will be all multiplied by the lower, middle, and upper points, Table 7. All other values will be calculated in the same way.

$\left((1 * 2 * 4 * 6 * 9)^{1 / 5},(1 * 3 * 5 * 7 * 9)^{1 / 5},(1 * 4 * 6 * 8 * 9)^{1 / 5}\right)=(3.3658,3.9363,4.4413)$

By implementing formula 4, the fuzzy weights for each criterion will be calculated. However, before this step, it should add all geometric values by applying formula $\mathbf{5}$ to get the summation of two fuzzy numbers.

$A_{1} * A_{2}=\left(I_{1}, m_{1}, u_{1}\right) *\left(I_{2}, m_{2}, u_{2}\right)=\left(I_{1}+I_{2}, m_{1}+m_{2}, u_{1}+u_{2}\right)(5)$

$(3.3658,3.9363,4.4413)$

$(1.6437,2.0321,2.4914)$

$(0.7962,0.9979,1.2457)$

$(0.3981,0.5306,0.6034)$

$(0.2228,0.2619,0.2941)$

$(6.4266,7.7588,9.0759)=$ Total

$(1 / 9.0759,1 / 7.7588,1 / 6.4266)=(0.1102,0.1289,0.1556)=$ reciprocal number

In the next step, the fuzzy geometric mean values were then multiplied by the reciprocal of the geometric mean summation $(0.1102,0.1289,0.1556)$.

$(3.3658,3.9363,4.4413) *(0.1102,0.1289,0.1556)=(0.3709+0.5074+0.6911) / 3=0.5231$ 
$(1.6437,2.0321,2.4914) *(0.1102,0.1289,0.1556)=(0.1811+0.2619+0.3876) / 3=0.2769$

$(0.7962,0.9979,1.2457) *(0.1102,0.1289,0.1556)=(0.0877+0.1286+0.1938) / 3=0.1367$

$(0.3981,0.5306,0.6034) *(0.1102,0.1289,0.1556)=(0.0439+0.0684+0.0939) / 3=0.0687$

$(0.2228,0.2619,0.2941) *(0.1102,0.1289,0.1556)=(0.0245+0.0337+0.0457) / 3=0.0346$

Furthermore, the De-Fuzzification process will be applied by using formula 6 . Thus, the lower, middle, and upper weights were added together and divided by 3 in order to get the fuzzy weights. Usually, the total of the criteria weights is not acceptable due to its values being more than 1 . Therefore, the weights should be normalized by dividing each weight by the total weight in order to obtain the normalized weights, as shown in Table 8.

Table 8

A De-fuzzification process and the normalized weights of drainage densities in the study area.

\begin{tabular}{|llll|}
\hline DD Values & The De-Fuzzification process & Fuzzy weights $\boldsymbol{w}_{\boldsymbol{i}}$ & Normalized weights \\
\hline 1 & $(0.3709+0.5074+0.6911) / 3=0.5231$ & $0.5231 / 1.04=0.5029$ & 0.5029 \\
\hline 2 & $(0.3709+0.5074+0.6911) / 3=0.5231$ & $0.2769 / 1.04=0.2662$ & 0.2662 \\
3 & $(0.3709+0.5074+0.6911) / 3=0.5231$ & $0.1367 / 1.04=0.1314$ & 0.1314 \\
4 & $(0.3709+0.5074+0.6911) / 3=0.5231$ & $0.0687 / 1.04=0.0661$ & 0.0661 \\
\hline 5 & $(0.3709+0.5074+0.6911) / 3=0.5231$ & $0.0346 / 1.04=0.0334$ & 0.0334 \\
\hline Total & & 1.04 & 1.00 \\
\hline
\end{tabular}

As a result, the steps outlined in Table 7 were applied to all criteria to obtain normalized weights for each criterion and sub-criteria in order to determine the potential groundwater zones in the study area.

\subsubsection{Groundwater Potential Index}

The Groundwater Potential Index (GWPI) is a dimensionless quantification index method that combines thematic layers to produce groundwater potential scores for various locations. The fuzzy-AHP method was used to determine the ratings and weight values for each of the parameters [32], which were then used to calculate the GWPI as follows:

GWPI $=\left[R_{w} * R_{r}+L_{w} * L_{r}+G_{w} * G_{r}+S I_{w} * S I_{r}+L_{w} * L_{r}+D_{d w} * D_{d r}+L_{w} * L_{r}+S_{w} * S_{r}\right](9)$

where GWPI stands for Groundwater Potential, R stands for rainfall, L stands for lithology, Ge stands for geology, SI stands for slope, Lu stands for land use/land cover, Dd stands for drainage density, LN stands for lineament, and $\mathrm{S}$ stands for slope. In addition, the weight of each thematic layer used is marked by the subscript ' $w$,' and the rating of the features in each thematic layer is marked by the subscript ' $r$.'

The parameters in this study were weighted based on the study area's hydrogeological properties and expert opinion, and the weight values and ratings of each parameter and sub-class were then used to 
calculate the groundwater potential index (GWPI) using equation 9.

\section{Results}

The availability of groundwater generally depends on rainfall, geology, lithology, soil, lineament density, drainage density, lulc, and other factors. Hence, all thematic maps of the current study area have been prepared according to the previously described methods. The following is a description of the prominent aspects of these topics. Due to the identification of appropriate recharge zones, eight factors were used to determine the highly penetrable and porous terrain.

\section{Rainfall}

The rainfall map of EB is shown in Figure 3a. The maximum amount of rainfall is about $576.9 \mathrm{~mm} / \mathrm{year}$, and the minimum value is about $281 \mathrm{~mm} /$ year. Furthermore, as you move westward, the amount of precipitation decreases gradually. The mean annual precipitation of this basin was about $467 \mathrm{~mm}$ during the last 20 years (2000-2020). Generally, the climatic factors that affect the hydrogeological conditions of groundwater aquifers have a direct impact on these aquifers. Precipitation is the primary source of groundwater recharge, and it has an impact on other meteorological factors such as temperature, relative humidity, wind speed, and direction [43].

\section{Geology}

Five geological classes were recognized in the EB based on their relative importance and impact on groundwater potential. The study area's dominant units are the quaternary deposit (polygenetic deposit) and the Bai-Hassan formations, which have good permeability and play an important role in groundwater supply and characterize the rainwater harvesting area. Thus, the surface drainage network contributes to the accumulation of surface flows in this area. Different geologic materials will have different characteristics for holding water beneath an aquifer system, Figure 3b, [43].

\section{Lithology}

Mainly, the occurrence and distribution of groundwater are influenced by lithology, thus it is one of the significant factors that control the quantity and quality of groundwater occurrences in the study area. Consequently, there is an important relationship between lithology and the availability of groundwater, which influences groundwater recharge by controlling water flow percolation [56]. The lithological features of the study area are mainly formed by the polygenetic environment, which is mainly a composite of alluvial sediments such as silt, clay, sand, and a mixture of gypsum and iron; and conglomerate aquifers in the quaternary and Pliocene within the formation of Bai Hassan [43]. A small portion of a fluvial environment can be seen in the north of the study area, with a little portion of the shallow water sub-continental environment and lagoon, Figure 3c. The lithology theme was included in this study as an important factor affecting the groundwater, despite some investigations having observed lineaments and drainage characters as a function of primary and secondary porosity [57]. 


\section{LULC}

Land use/cover is a significant factor in recharging groundwater. It encompasses the distribution of soil sediments, urban areas, and vegetation cover. The study area was categorized into five classes namely; cropland $1389.05 \mathrm{~km}^{2}$, which has a maximum area, rangeland $1013.3 \mathrm{~km}^{2}$, built-up area $431.32 \mathrm{~km}^{2}$, barren land $305.11 \mathrm{~km}^{2}$, and water bodies $17.063 \mathrm{~km}^{2}$. Cropland and rangeland have a better ability to recharge and retain groundwater than built-up and barren land areas. Cropland is found throughout the northwest and southwest of the study area, while the rangeland covers the eastern part of the basin, Figure $3 \mathrm{~d}$. Groundwater is more likely to be recharged and stored in dense agriculture areas, whereas infiltration and recharge are less likely in exposed bare rock and built-up areas [58].

\section{Soil Type}

Another significant parameter that influences the occurrence and distribution of groundwater is soil, which has an important role in recharging groundwater [56]. Four types of soil dominate the study area, viz., (1) brown soils, deep phase, (2) brown soils, medium and shallow phases, (3) lithosolic soils in limestone, and (4) lithoslolic soils in sandstone and gypsum. Moreover, the first type dominates $83.1 \%$ of the total area and has gravel silt-clay layers with surface cracks under the brown soil layer, which is an appropriate type of soil for infiltration. The second type covers $13.64 \%$ and represents brown soil with medium to shallow phases covered by a layer of gravel and silty loam, which can be considered a proper type of soil for infiltration, while the third and fourth types are very poor classes for infiltration. Low to moderate runoff potentials are present in most of the areas (first and second types) due to the high rate of infiltration and consist mainly of sand, clay, and Bakhtyari group conglomerates, Figure 4a, [59].

\section{Slope}

The slope gradient has a direct impact on rainfall infiltration. Since the water flows quickly down a steep slope during rainfall, it does not have adequate time to infiltrate the surface and recharge the saturated zone. Thus, the higher the slope, the higher the runoff will be. From a groundwater perspective, the lower area with lower values will have higher groundwater potential due to its lower slope and vice versa.

The slope of the EB was derived from the digital elevation model (DEM) and was classified into five categories ranging from 0 to 57.86 . The areas having a $0-3.6^{\circ}$ slope are categorized as "very good" areas and cover $34.50 \%$ of the study area. While areas that have a $3.6^{\circ}$ to $7.03^{\circ}$ slope are categorized as "good" areas and cover $36.32 \%$ of the study area. "Moderate" areas have a slope degree of $7.03^{\circ} 0-11.34^{\circ}$ and cover $19.74 \%$ of the area. Those areas with $11.34^{\circ}-17.92^{\circ}$ slope are considered "poor" for groundwater occurrence and cover $7.45 \%$. However, areas that have $17.92^{\circ}-57.86^{\circ}$ of slope and cover $1.99 \%$ are defined as "very poor" due to the higher slope, which causes higher runoff due to increasing the amount of runoff with slope. Thus, roughly more than $70 \%$ of the EB is dominated by the flat terrain in the central part, which reasonably reduces the runoff movement, Figure $4 \mathrm{~b}$.

\section{Lineament Density}


A lineament density is a manifestation of fractures, faults, and joints in a geographical landscape, which can be calculated by dividing the total length of all lineaments by the area under consideration. It is also a good indicator for understanding the relationship between the surface water infiltration and fracture structure, thus signifying a permeable zone. Increased lineament density designates the highest potential for groundwater recharge [60].

The lowest value of lineament density ranges between 0 and $0.15 \mathrm{~km} / \mathrm{km}^{2}$. This part covers almost 1011 $\mathrm{km}^{2}$ of the total area. However, the highest value of lineament density in the study area ranges between 0.60 and $0.75 \mathrm{~km} / \mathrm{km}^{2}$ and covers $216 \mathrm{~km}^{2}$, which means the higher the probability of groundwater occurrence, while the moderate value of lineament density ranges between 0.30 and $0.45 \mathrm{~km} / \mathrm{km}^{2}$ and covers $761 \mathrm{~km}^{2}$ of the total area Figure 4c.

\section{Drainage Density}

Drainage density $\left(D_{d}\right)$ is the ratio between the total length of all streams and rivers and the unit area of the basin [61]. The relationship between permeability and drainage density is inverse. Therefore, $D_{d}$ decreases with the increasing infiltration capacity of the underlying rocks. Furthermore, when the $D_{d}$ has a high value, less infiltration and a higher chance of runoff are expected [60,62]. In the current study, a drainage density map was applied to define the highly permeable and porous terrain due to the identification of suitable recharge sites. The $D_{d}$ of the current study area has been categorised into five classes: "very high" (3.50-4.38 km/ km²) covers $305 \mathrm{~km}^{2}$ of the area, "high" (2.62-3.50 km/ km²) covers 601 km², "medium" (1.75-2.62 km/ km²) covers 878 km², "low" $(0.87-1.75$ km/ km²) covers 797 km² and "very low" (0-0.87 km/ km²) covers $573 \mathrm{~km}^{2}$, respectively. Furthermore, taking into account from a recharge point perspective, areas with low $D_{d}$ are given high weight and vice versa. The drainage density map displays five drainage densities that have been identified and mapped as shown in, Figure 4d. Accordingly, the lower the drainage density, the higher the probability of groundwater. Therefore, the lowest $D_{d}$ surrounds the perimeter of the study area and covers $18.17 \%$ of the total area, which indicates a good potential zone for recharging the aquifer. Whereas the areas towards the center of the study contain moderate to high drainage densities.

\section{Discussion}

The results showed that groundwater in EB follows the topography of the region, thus it flows from the east to the west, which was also confirmed by $[40,63,64]$. Moreover, the east side revealed that it contains deeper groundwater levels than the west part of the study area, which has shallower groundwater levels, Figure 5. Therefore, groundwater withdrawals have expanded dramatically during the last 30 years, globally and in EB particularly.

The groundwater recharge potential map was created by using weighted overlay analysis in a GIS environment through combining multiple environmental factors. The results showed that the rainfall and 
the lithological factor were the most suitable and promising groundwater potential zone due to the good porosity and permeability caused by the loose and unconsolidated sediments, which almost covers $80 \%$ of the current study [63]. Furthermore, groundwater is a gravitational pull and flows slowly (years, decades, even thousands of years) through pores and fractures in the rocks, eventually discharging (draining) into springs, rivers, lakes, and the sea [9]. Therefore, as more permeable sediments become available, aquifer transmissivity often increases as in the central part of the syncline, along with river courses, and within alluvial fans in the study area [44].

The effect of the rainfall was the major source of groundwater storage. Thus, the higher the precipitation intensity, the greater the groundwater recharge and vice versa. Overall, the GWRPZ map illustrates that the study area is a suitable zone for aquifer recharge. Therefore, this study is useful for decision-makers to define a plan to recharge groundwater. Furthermore, a careful management plan is required to make better use of the groundwater resources [20].

The sustainable management of water resources that improves the environmental condition and increases water management can be provided through the involvement of rainwater harvesting areas and groundwater recharge zones, hence overcoming the problem of water scarcity [7]. The analysis of the groundwater potential area will depend on the experience of the study area. Therefore, the better you know the site, the better you can decide which factor to use. 
Table 9

Fuzzy weights and rating of parameters used and their attributes

\begin{tabular}{|c|c|c|c|c|}
\hline \multirow{2}{*}{ Parameters } & \multicolumn{4}{|c|}{ Fuzzy AHP } \\
\hline & Sub-classes & $\begin{array}{l}\text { Weight of the } \\
\text { parameters }\end{array}$ & $\begin{array}{l}\text { Rating of the } \\
\text { attribute class }\end{array}$ & $\begin{array}{l}\text { Total } \\
\text { weight }\end{array}$ \\
\hline \multirow[t]{4}{*}{ Lithology } & Fluvial environment & 0.3843 & 0.3716 & 0.1428 \\
\hline & Lagoon & & 0.0539 & 0.0207 \\
\hline & polygenetic environment & & 0.1708 & 0.0656 \\
\hline & $\begin{array}{l}\text { Shallow water to the sub- } \\
\text { continental environment }\end{array}$ & & 0.4037 & 0.1551 \\
\hline \multirow{5}{*}{$\begin{array}{l}\text { Drainage } \\
\text { Density }\left(\mathrm{km}^{-1}\right)\end{array}$} & $0-0.87$ & 0.0563 & 0.5029 & 0.0283 \\
\hline & $0.87-1.75$ & & 0.2662 & 0.0149 \\
\hline & $1.75-2.62$ & & 0.1314 & 0.0073 \\
\hline & $2.62-3.50$ & & 0.0661 & 0.0037 \\
\hline & $3.50-4.38$ & & 0.0334 & 0.0018 \\
\hline \multirow[t]{5}{*}{ Geology } & Polygenetic \& slope deposits & 0.1599 & 0.3737 & 0.0597 \\
\hline & Bai Hassan & & 0.3737 & 0.0597 \\
\hline & Fatha & & 0.0829 & 0.0132 \\
\hline & Injana & & 0.0389 & 0.0062 \\
\hline & Mukdadyah & & 0.1308 & 0.0209 \\
\hline \multirow{5}{*}{$\begin{array}{l}\text { Lineament } \\
\text { density }\end{array}$} & $0.60-0.75$ & 0.0155 & 0.5204 & 0.0080 \\
\hline & $0.45-0.60$ & & 0.2753 & 0.0042 \\
\hline & $0.30-0.45$ & & 0.1364 & 0.0021 \\
\hline & $0.15-0.30$ & & 0.0454 & 0.0007 \\
\hline & $0-0.15$ & & 0.0225 & 0.0003 \\
\hline LULC & Rangeland & 0.0393 & 0.1434 & 0.0056 \\
\hline \multicolumn{5}{|c|}{$\begin{array}{l}\text { The AHP approach was used to obtain weight values for all the thematic layers, followed by the fuzzy } \\
\text { rating values of the attribute classes and sub-classes for each individual thematic layer. Table } 9 \\
\text { displays that the most relevant parameter in the current work is lithology, having a weight value of } \\
0.3843 \text {, followed by rainfall and geology, with weight values of } 0.2515 \text { and } 0.1599 \text {, respectively. } \\
\text { Moreover, other factors affecting groundwater potential with their descending weights are slope } \\
(0.0696) \text {, drainage density }(0.0563) \text {, LULC }(0.0393) \text {, soil }(0.0236) \text {, and lineament density }(0.0155) \text {. }\end{array}$} \\
\hline
\end{tabular}




\begin{tabular}{|c|c|c|c|c|}
\hline & \multicolumn{4}{|c|}{ Fuzzy AHP } \\
\hline & Cropland & & 0.1199 & 0.0047 \\
\hline & Water bodies & & 0.6221 & 0.0244 \\
\hline & Barren land & & 0.0603 & 0.0023 \\
\hline & Built-up & & 0.0541 & 0.0021 \\
\hline \multirow[t]{5}{*}{ Rainfall } & $528-576$ & 0.2515 & 0.7318 & 0.1840 \\
\hline & $491-528$ & & 0.1519 & 0.0382 \\
\hline & $442-491$ & & 0.0631 & 0.0158 \\
\hline & $365-442$ & & 0.0363 & 0.0091 \\
\hline & $281-365$ & & 0.0151 & 0.0037 \\
\hline \multirow[t]{5}{*}{ Slope } & $0-3.6$ & 0.0696 & 0.5018 & 0.0349 \\
\hline & $3.6-7.03$ & & 0.2656 & 0.0184 \\
\hline & $7.03-11.34$ & & 0.1312 & 0.0091 \\
\hline & $11.34-17.92$ & & 0.0718 & 0.0049 \\
\hline & $17.92-57.86$ & & 0.0296 & 0.0020 \\
\hline \multirow[t]{4}{*}{ Soil } & Brown soils, deep phase & 0.0236 & 0.4566 & 0.0107 \\
\hline & $\begin{array}{l}\text { Brown soils, medium, and } \\
\text { shallow phase }\end{array}$ & & 0.2097 & 0.0049 \\
\hline & Lithosolic soils in Limestone & & 0.1095 & 0.0025 \\
\hline & $\begin{array}{l}\text { Lithosolic soils in sandstone } \\
\text { and gypsum }\end{array}$ & & 0.2242 & 0.0052 \\
\hline \multicolumn{5}{|c|}{$\begin{array}{l}\text { The AHP approach was used to obtain weight values for all the thematic layers, followed by the fuzzy } \\
\text { rating values of the attribute classes and sub-classes for each individual thematic layer. Table } 9 \\
\text { displays that the most relevant parameter in the current work is lithology, having a weight value of } \\
0.3843 \text {, followed by rainfall and geology, with weight values of } 0.2515 \text { and } 0.1599 \text {, respectively. } \\
\text { Moreover, other factors affecting groundwater potential with their descending weights are slope } \\
(0.0696) \text {, drainage density }(0.0563) \text {, LULC }(0.0393) \text {, soil }(0.0236) \text {, and lineament density }(0.0155) \text {. }\end{array}$} \\
\hline
\end{tabular}

However, the F-AHP specified the total weight and rating values for each individual sub-category. From Table 9, the rainfall sub-class (528-576) was the most effective parameter with a weight value of 0.1840 , followed by sub-categories of shallow water to the sub-continental environment and fluvial environment factors with weight values of 0.1551 and 0.1428 , respectively.

Furthermore, the groundwater potential zone, Figure 5, shows that about $210.85 \mathrm{~km} 2$ of the total area falls under the "very high GWRPZ," however, the "high" GWRPZ occupies about 188.94 km2, and 573.06 
km2 lies under the "moderate" GWRPZ. Conversely, the "low GWRPZ" covers the largest area of the study area, with $1956.48 \mathrm{~km} 2$, whereas $216.34 \mathrm{~km} 2$ of coverage lies under the "very low GWRPZ." Thus, the sustainable development of groundwater in this study basin could benefit from the GWRPZ map. This implies that recharging the groundwater is best done in areas with "very high" and "high" potential groundwater. This can also be confirmed by the depth of wells, which have lower depths in meters compared to the other well sites.

Frankly speaking, artificial recharge of aquifers is necessary for the research area to avoid low groundwater levels, increased expenses for the user, reduced water availability in water bodies, and land subsidence [65]. There are adequate flat regions that are suitable for spreading water in a thin sheet and achieving a higher rate of vertical infiltration of the study area. Moreover, around one-third of the area has a very high potential for infiltration since it forms from the study area's alluvial areas.

Additionally, it is observed that wells, symbolized in a triangle, are located in the north and south-western part of the basin and are mostly close to and even far from the GZR, have a very high groundwater potential, Figure 6 . This reveals that some of the western parts of the EB are an active zone for recharging the groundwater table and it can be selected for an artificial recharge zone. The wells from the central and eastern parts of the basin, on the other hand, show deeper to deepest groundwater tables, respectively, and are in the basin's moderate to very low groundwater potential zones. As a result, the groundwater potential zone can be seen to have a negative relationship with groundwater level.

Last and not least, groundwater recharge in the EB comes primarily from direct rainfall, infiltration through highly permeable sediments, faults, fissures, joints, and fractures in carbonate formations. In addition, surface run-off in rivers and valleys recharges the groundwater table [44].

Furthermore, as shown in Table 10, the lower groundwater potential zone is the deepest part of the groundwater level. Consequently, the Greater Zab River is the primary source of groundwater discharge, as Saether and De Caritat [5] have also confirmed. Besides, it can be observed that the minimum well depth is within the "low" to "very low" groundwater potential zones and vice versa. The resulting groundwater potential map is highly accurate in comparison to groundwater table maps and can be used to plan groundwater exploration and management in the EB. 
Table 10

Area calculation for groundwater potential zone in Erbil Basin

\begin{tabular}{|lllll|}
\hline Potentiality Level & Area $(\%)$ & Total Area $\left(\mathrm{km}^{2}\right)$ & Depth of wells $(\mathrm{m})$ & Number of Wells \\
\hline Very Low & 6.86 & 216.34 & $518.49-641.55$ & 3 \\
\hline Low & 62.20 & 1956.48 & $445.57-518.49$ & 1 \\
\hline Moderate & 18.23 & 573.06 & $378.72-445.57$ & 6 \\
\hline High & 6 & 188.94 & $320.99-378.72$ & 8 \\
\hline Very High & 6.7 & 210.85 & $254.15-320.99$ & 10 \\
\hline
\end{tabular}

To be concluded, the groundwater potential zone map created in this study is extremely useful and can be used as a guide for concerned decision-makers and the government in planning future artificial recharge projects to ensure sustainable groundwater utilization for current and future generations in the study area [37].

\subsection{Validation of GWPZ maps}

There are many methods to support the groundwater potential maps, such as receiver performance analysis (ROC), curve area (AUC), groundwater yield of wells performance during field visits or by available water table data $[66,67]$.

To verify the accuracy of the Fuzzy-AHP model, 28 observation wells of groundwater table data from the General Directorate of Subsurface Water were obtained and compared to a GWPZ map. Wells' locations were plotted on a post-GWRPZ map in ArcGIS. The depth of the groundwater table below the surface ranges between 254.15 and 641.55 meters. The findings revealed that 9 of the 28 wells were accurately located in potential zones of very high groundwater Figure 6 , which were classified as having a shallower depth to groundwater level with depths ranging from 254.15 to 320.99 meters, compared to the other wells, which had depths ranging from 518.49 to 641.55 meters. Subsequently, six out of eight wells were identified in the high groundwater recharge zones, with depths ranging from 320.99 to 378.72 meters. While five of six wells belonged to areas with moderate potential for groundwater. However, one well was located in the lower GWRPZ, and two of the last three wells were located in the very low areas, Figures 6 \& 7. This indicates that the GWRPZ generated by the F-AHP model was consistent with the ground truth data (well locations). Furthermore, the validation results show that the database with techniques applied to build GWPZ models for potential groundwater zones has shaped accurate results by analyzing the suitability of the significant weights of the factors.

\section{Conclusions}

The main themes of the present study were the availability of groundwater and associated human perceptions. The delineation of potential groundwater zones was performed by applying "weighted 
overlay classification" using the spatial analyst method in ArcGIS. This paper research demonstrates the usefulness of RS, GIS, and the integrated Fuzzy-AHP technique for the identification of groundwater potential zones. Concerning the relative importance of various parameters of the current study, rainfall and lithology were the two most influential ones, while geology, slope, drainage density, LULC, lineament density, and soil were the least influential. The sub-categories of rainfall (528-576) $\mathrm{mm}$, shallow water to the sub-continental environment, and fluvial environment factors with weight values $0.1840,0.1551$, and 0.1428 , respectively, were the most effective criteria for the potential area of groundwater in the study area.

The results of this work are useful for administrators and decision-makers to organize groundwater for current and future needs. There is a need for potential groundwater research in Erbil province due to very rapid urbanization, agricultural, and industrial development. To improve the management and development of groundwater resources in the field, a scientific plan is required. In addition to the important results, this study is extremely valuable for groundwater planning, sustainable management, and artificial recharge structures in the EB.

\section{Recommendations}

According to this study, a series of weirs (small dams) should be built along the Bastora River's valley to raise the groundwater level, which is critical, since the composition of this valley mainly consists of conglomerates and gravels according to geological and lithological settings that infiltrate the unconfined and semi-confined aquifer. Moreover, Bastora valley was once a riverbed [68], it is now a full-fledged valley, especially during summer and autumn. It is noteworthy that in winter and spring there is very little runoff. It can be explained that the groundwater flows from northeast to the southwest in the study area, which could be related to groundwater recharge of the groundwater by the Bastora valley in the past, and it was a groundwater recharge area of the Erbil Basin. As a result, the widespread and increasing use by the residents of Erbil city has led to the depletion of groundwater.

Additionally, it is also necessary to artificially recharge the wells with a pumping rate of $10,000-15,000$ $\mathrm{m}^{3}$ /day distributed among 20 to 30 injection wells, which leads to an annual increase in groundwater levels, in the selected areas. Hassan, Nile [69] investigated the simulation work and found that injecting treated water through 20 wells would raise the groundwater table by more than $91 \mathrm{~km}^{2}$ and $136 \mathrm{~km}^{2}$ for pumping rates of 5000 and $10,000 \mathrm{~m}^{3} /$ day, respectively. Moreover, it will cause an annual increase in the Kerbala Desert in Iraq of 7 to 20 centimeters.

\section{Declarations}

\section{Acknowledgments}

This research did not receive any specific grants from funding agencies in the public, commercial, or notfor-profit sectors. 


\section{Conflict of Interest}

The author declares no conflict of interest.

\section{References}

1. Carrard N, Foster T, Willetts J (2020) Correction: Groundwater as a source of drinking water in southeast asia and the pacific: A multi-country review of current reliance and resource concerns. [Water (2019), 11,(1605. Water (Switzerland),

2. Cobbing $J$ et al (2013) Assessing and managing groundwater in different environments. CRC Press

3. Neff BP et al (2020) A hydrologic landscapes perspective on groundwater connectivity of depressional wetlands. Water 12(1):50

4. Winter TC (1999) Ground water and surface water: a single resource, vol 1139. Diane Publishing

5. Saether OM, De Caritat P (1996) Geochemical processes, weathering and groundwater recharge in catchments. CRC Press

6. Kinzelbach W et al (2003) Sustainable groundwater management--Problems and scientific tool. Episodes-Newsmagazine of the International Union of Geological Sciences 26(4):279-284

7. Akter $A$ et al (2020) Predicting groundwater recharge potential zones using geospatial technique. Sustainable Water Resources Management 6(2):1-13

8. Stevanovic Z, lurkiewicz A (2009) Groundwater management in northern Iraq. Hydrogeol J 17(2):367-378

9. Shah RA, Lone SA (2019) Hydrogeomorphological mapping using geospatial techniques for assessing the groundwater potential of Rambiara river basin, western Himalayas. Applied Water Science 9(3):1-11

10. Scanlon BR et al (2006) Global synthesis of groundwater recharge in semiarid and arid regions. Hydrological Processes: An International Journal 20(15):3335-3370

11. Thomas BF, Famiglietti JS (2019) Identifying climate-induced groundwater depletion in GRACE observations. Sci Rep 9(1):1-9

12. Shao $Z$ et al (2020) Integrated remote sensing and GIS approach using Fuzzy-AHP to delineate and identify groundwater potential zones in semi-arid Shanxi Province, China, vol 134. Environmental Modelling \& Software, p 104868

13. Machiwal D, Jha MK, Mal BC (2011) Assessment of groundwater potential in a semi-arid region of India using remote sensing, GIS and MCDM techniques. Water Resour Manage 25(5):1359-1386

14. Abrams W et al (2018) Delineation of groundwater potential (GWP) in the northern United Arab Emirates and Oman using geospatial technologies in conjunction with Simple Additive Weight (SAW), Analytical Hierarchy Process (AHP), and Probabilistic Frequency Ratio (PFR) techniques. J Arid Environ 157:77-96 
15. Souissi D et al (2018) Mapping groundwater recharge potential zones in arid region using GIS and Landsat approaches, southeast Tunisia. Hydrol Sci J 63(2):251-268

16. El-Magd SAA, Eldosouky AM (2021) An improved approach for predicting the groundwater potentiality in the low desert lands; El-Marashda area, Northwest Qena City, Egypt. J Afr Earth Sc 179:104200

17. Al Kuisi M et al (2014) Groundwater vulnerability and hazard mapping in an arid region: case study, Amman-Zarqa Basin (AZB)-Jordan. Journal of Water Resource and Protection, 2014

18. Shentsis I et al (1999) Assessment of transmission losses and groundwater recharge from runoff events in a wadi under shortage of data on lateral inflow, Negev, Israel. Hydrol Process 13(11):16491663

19. Bilal A, Ammar $O$ (2002) Rainfall water management using satellite imagery-example from Syria. Int J Remote Sens 23(2):207-219

20. Çelik R (2019) Evaluation of groundwater potential by GIS-based multicriteria decision making as a spatial prediction tool: case study in the Tigris River Batman-Hasankeyf Sub-Basin, Turkey. Water 11(12):2630

21. Subyani AM (2004) Use of chloride-mass balance and environmental isotopes for evaluation of groundwater recharge in the alluvial aquifer, Wadi Tharad, western Saudi Arabia. Environ Geol 46(67):741-749

22. Saaty TL (1980) The analytic hierarchy process (AHP). The Journal of the Operational Research Society 41(11):1073-1076

23. Ho W (2008) Integrated analytic hierarchy process and its applications-A literature review. Eur J Oper Res 186(1):211-228

24. Ortuño M (2013) Multi-criteria decision analysis (MCDA). Encyclopedia of Sciences and Religions, : p. 1376

25. Mardani A et al (2015) Multiple criteria decision-making techniques and their applications-a review of the literature from 2000 to 2014. Economic research-Ekonomska istraživanja 28(1):516-571

26. NGUYEN P-H (2021) A Fuzzy Analytic Hierarchy Process (FAHP) Based on SERVQUAL for Hotel Service Quality Management: Evidence from Vietnam. The Journal of Asian Finance Economics and Business 8(2):1101-1109

27. El-Din HK, Abd El HE, Munim, Mahdi H (2019) Decision-Making in Fuzzy Environment: $A$ Survey.Application of Decision Science in Business and Management, : p.15

28. Reig-Mullor J, Pla-Santamaria D, Garcia-Bernabeu A (2020) Extended fuzzy analytic hierarchy process (E-fahp): A general approach. Mathematics, 8(11): p. 2014

29. Lee SK, Mogi G, Hui K (2013) A fuzzy analytic hierarchy process (AHP)/data envelopment analysis (DEA) hybrid model for efficiently allocating energy R\&D resources: In the case of energy technologies against high oil prices. Renew Sustain Energy Rev 21:347-355 
30. Afolayan AH, Ojokoh BA, Adetunmbi AO (2020) Performance analysis of fuzzy analytic hierarchy process multi-criteria decision support models for contractor selection. Scientific African 9:e00471

31. Şener E, Şener Ş, Davraz A (2018) Groundwater potential mapping by combining fuzzy-analytic hierarchy process and GIS in Beyşehir Lake Basin, Turkey. Arab J Geosci 11(8):1-21

32. Kumar M, Singh P, Singh P Fuzzy AHP based GIS and Remote Sensing Techniques for the Groundwater Potential Zonation for Bundelkhand Craton Region, India. Geocarto International, 2021(just-accepted): p. 1-21

33. Van Laarhoven PJ, Pedrycz W (1983) A fuzzy extension of Saaty's priority theory. Fuzzy Sets Syst 11(1-3):229-241

34. Chang D-Y (1996) Applications of the extent analysis method on fuzzy AHP. Eur J Oper Res 95(3):649-655

35. Ahmed A, Alrajhi A, Alquwaizany AS (2021) Identification of Groundwater Potential Recharge Zones in Flinders Ranges, South Australia Using Remote Sensing, GIS, and MIF Techniques. Water 13(18):2571

36. Vafaei N, Ribeiro RA, Camarinha-Matos LM (2016) Normalization techniques for multi-criteria decision making: analytical hierarchy process case study. in doctoral conference on computing, electrical and industrial systems. Springer

37. Chaudhry AK, Kumar K, Alam MA (2021) Mapping of groundwater potential zones using the fuzzy analytic hierarchy process and geospatial technique. Geocarto International 36(20):2323-2344

38. Al-Ansari N, Essaid H, Salim Y (1981)Water resources in Iraq.

39. Kznee A (1997) Erbil and drinking water in the past and the present, the Ministry of Education.Erbil, 29

40. Jwan SM, Salah FSA, Shuokr QA (2021) Assessment of sustainability and management for groundwater source in Erbil city. Recycling and Sustainable Development 14(1):41-50

41. Al-Ansari N (2021) Water Resources of Iraq. Journal of Earth Sciences and Geotechnical Engineering 11(2):15-34

42. Habib H, Al-Saigh N, Hassan Z (1990) Geochemistry of undergroundwater in Erbil City, Iraq. in conference of SDRC, Mosul.

43. Saleh SA, Al-Ansari N, Abdullah T (2020) Groundwater Hydrology in Iraq. Journal of Earth Sciences and Geotechnical Engineering 10(1):155-197

44. Al-Jiburi HK, Al-Basrawi NH Hydrogeology of the low folded zone.Iraqi Bulletin of Geology and Mining, 2012(5): p.133-157

45. Shekha YA (2016) Evaluation of water quality for Greater Zab River by principal component analysis/factor analysis. Iraqi Journal of Science 57(4B):2650-2663

46. Alpagut B et al (2021) A GIS-Based Multicriteria Assessment for Identification of Positive Energy Districts Boundary in Cities. Energies 14(22):7517 
47. Owolabi ST et al (2020) A groundwater potential zone mapping approach for semi-arid environments using remote sensing (RS), geographic information system (GIS), and analytical hierarchical process (AHP) techniques: a case study of Buffalo catchment, Eastern Cape, South Africa. Arab J Geosci 13(22):1-17

48. Das $\mathrm{M}$ et al (2021) Assessing groundwater status and human perception in drought-prone areas: a case of Bankura-I and Bankura-II blocks, West Bengal (India). Environ Earth Sci 80(18):1-23

49. Chen G, Pham TT, Boustany N (2001) Introduction to fuzzy sets, fuzzy logic, and fuzzy control systems. Appl Mech Rev 54(6):B102-B103

50. Mentes A, Helvacioglu IH (2011) Review of fuzzy set theory applications in safety assessment for marine and offshore industries. in International Conference on Offshore Mechanics and Arctic Engineering.

51. Tiwary U (2009) Fuzzy Sets (Type-1 and Type-2) and their Applications.

52. Sridharan M et al (2018) Prediction of solar photovoltaic/thermal collector power output using fuzzy logic.Journal of Solar Energy Engineering, 140(6)

53. Nagarajan R, Thirunavukarasu R (2019) A fuzzy-based decision-making broker for effective identification and selection of cloud infrastructure services. Soft Comput 23(19):9669-9683

54. Noughabi EAZ et al (2017) Handbook of research on data science for effective healthcare practice and administration. IGI Global

55. Buckley JJ (1985) Fuzzy hierarchical analysis. Fuzzy Sets Syst 17(3):233-247

56. Dar T, Rai N, Bhat A (2021) Delineation of potential groundwater recharge zones using analytical hierarchy process (AHP). Geology, Ecology, and Landscapes, 5(4): p. 292-307

57. Yeh H-F et al (2016) Mapping groundwater recharge potential zone using a GIS approach in Hualian River, Taiwan. Sustainable Environment Research 26(1):33-43

58. Ranasinghe-Arachchilage $C$ et al (2021) Comparison of Multicriteria Decision-Making Techniques for Groundwater Recharge Potential Zonation: Case Study of the Willochra Basin, South Australia. Water 13(4):525

59. Buringh P (1960) Soils and soil conditions in Iraq. Ministry of agriculture Baghdad

60. Saranya T, Saravanan S (2020) Groundwater potential zone mapping using analytical hierarchy process (AHP) and GIS for Kancheepuram District, Tamilnadu, India.Modeling Earth Systems and Environment, : p.1-18

61. Strahler AN (1957) Quantitative analysis of watershed geomorphology. Eos, Transactions American Geophysical Union, 38(6): p. 913-920

62. Dwivedi C et al (2021) Groundwater Potential Zone Delineation in Hard Rock Terrain for Sustainable Groundwater Development and Management in South Madhya Pradesh, India. Geography, Environment, Sustainability, 14(1): p. 106-121

63. Al-Tamir A (2008) Interpretation of ground water quality data variation in Erbil city, Northern Iraq. AlRafidain Engineering Journal (AREJ) 16(2):24-30 
64. Gardi SQS, Asfahani J (2019) Subsurface tectonic characterizations by the use of geo-electrical resistivity technique and their implications on environmental soil and groundwater at Erbil dumpsite, west of Erbil city-Iraqi Kurdistan region, vol 49. Contributions to Geophysics \& Geodesy, pp 325354. 3

65. Veeranna J, Jeet P (2020) Groundwater Recharges Technology for Water Resource Management: A Case Study, in Groundwater. IntechOpen

66. Rajasekhar M et al (2019) Delineation of groundwater potential zones in semi-arid region of Jilledubanderu river basin, Anantapur District, Andhra Pradesh, India using fuzzy logic, AHP and integrated fuzzy-AHP approaches. HydroResearch 2:97-108

67. Singh P et al (2021) Fuzzy analytical hierarchy process based GIS modelling for groundwater prospective zones in Prayagraj, India. Groundwater for Sustainable Development 12:100530

68. Ghaib F (2009) The Assessment of Erbil Aquifer Using Geo-electrical Investigation (Iraqi Kurdistan Region). Journal of applied sciences in environmental sanitation 4(1):43-54

69. Hassan WH et al (2021) A feasibility assessment of potential artificial recharge for increasing agricultural areas in the kerbala desert in iraq using numerical groundwater modeling. Water 13(22):3167

\section{Figures}

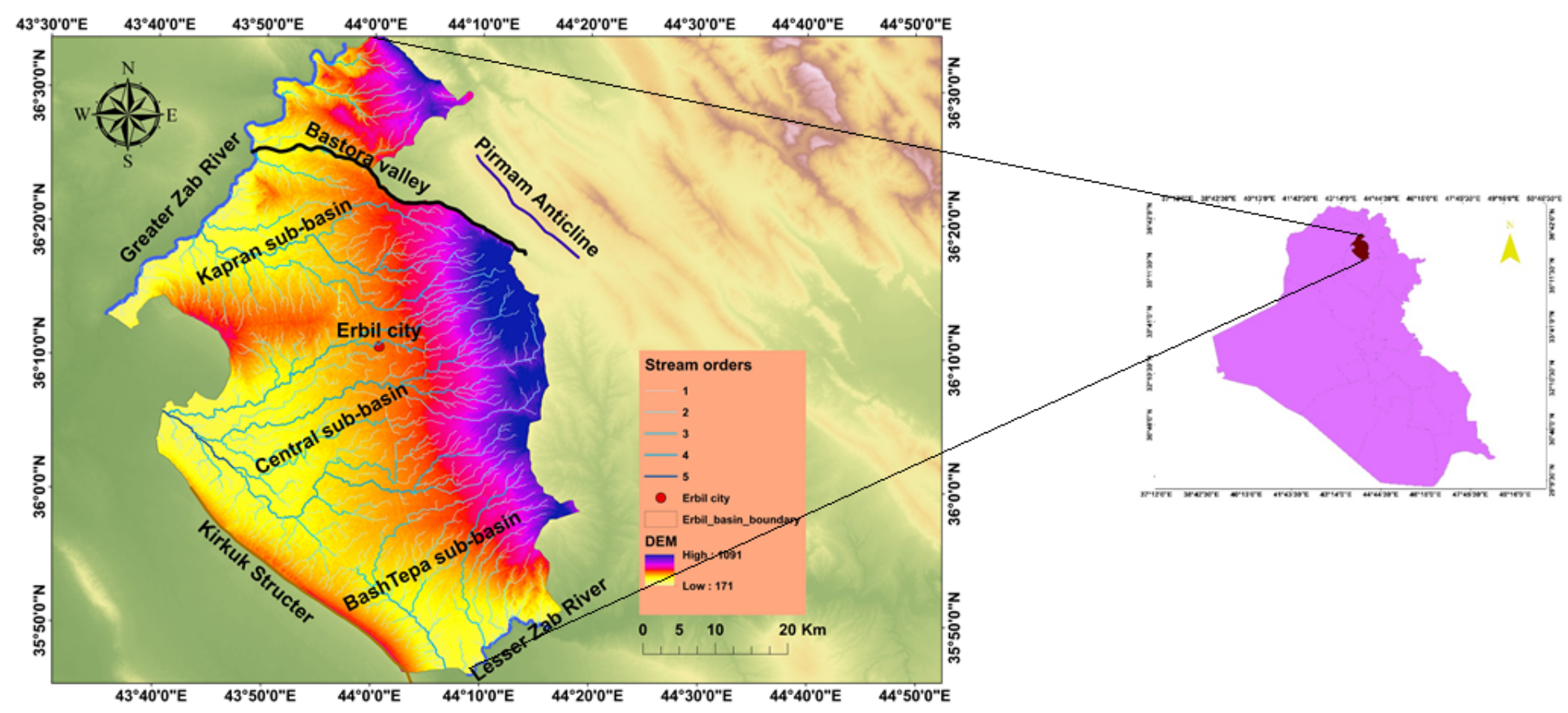

\section{Figure 1}

Location map of Erbil Basin in the Kurdistan Region of Iraq. 


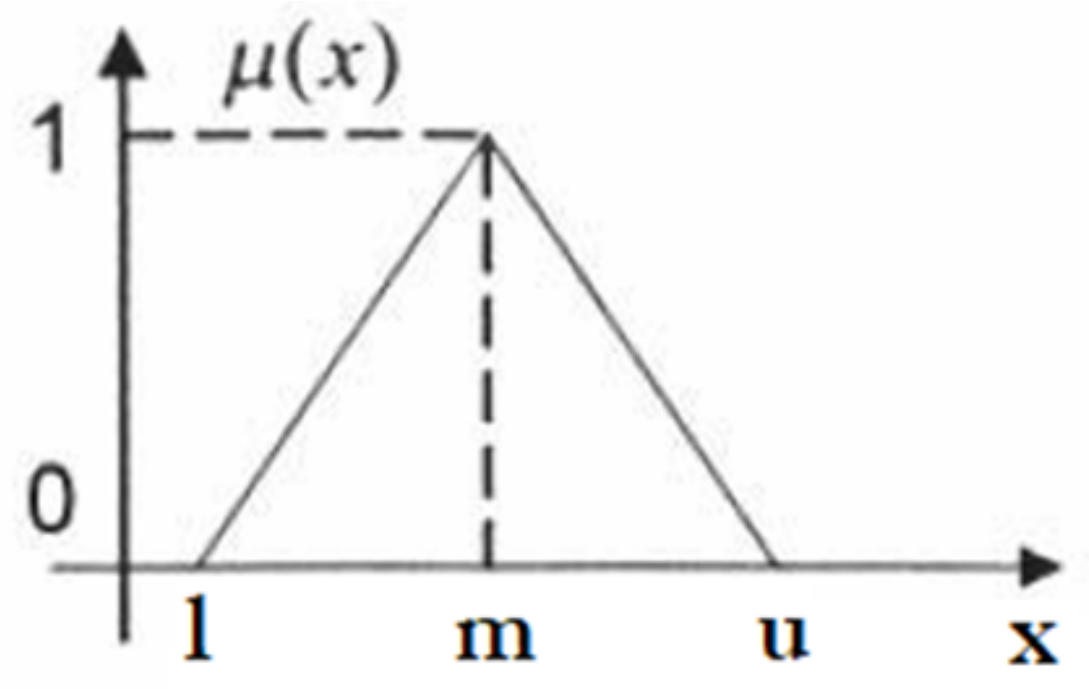

Figure 2

Membership function for triangular fuzzy numbers adapted after Shao, Huq [12].

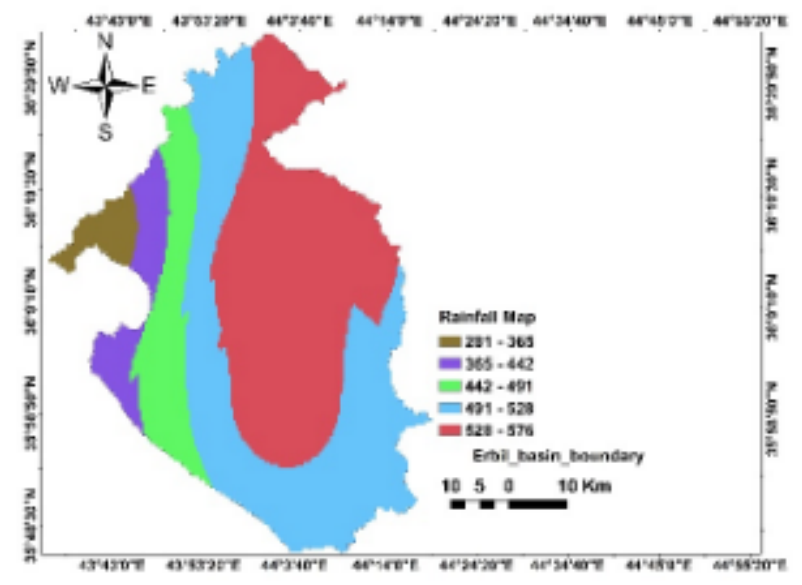

a

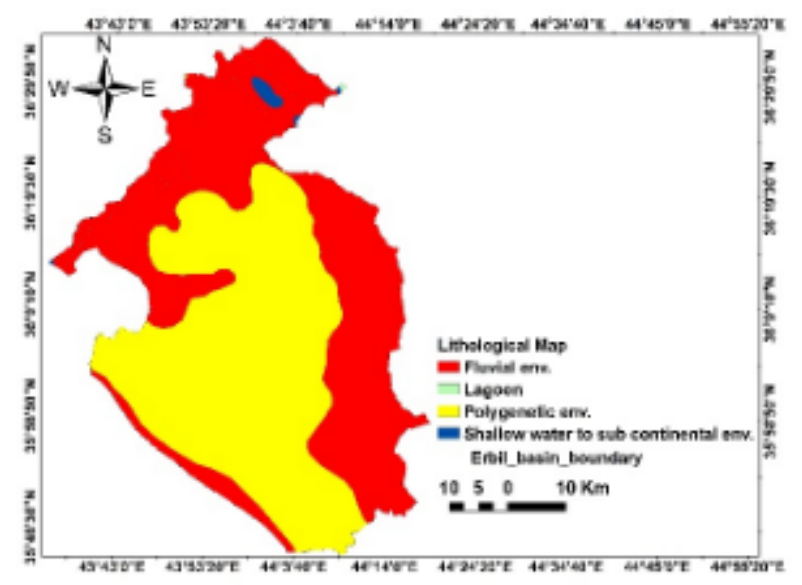

c

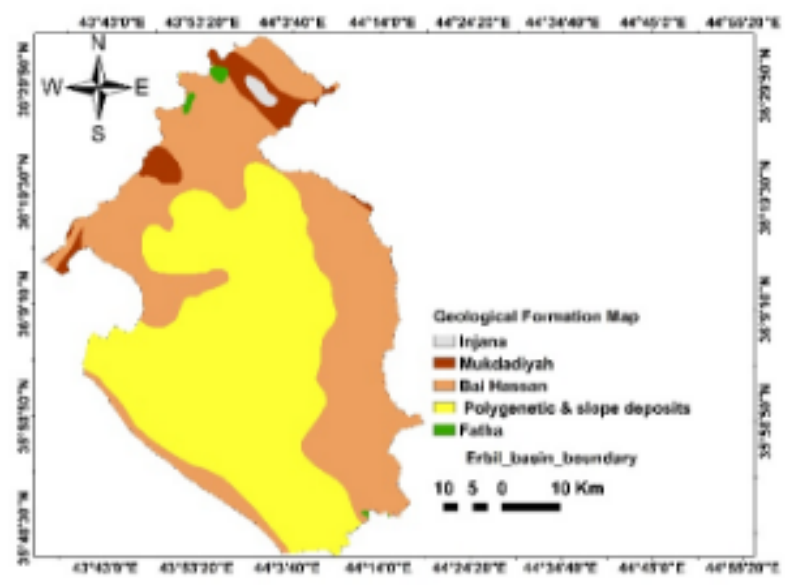

b

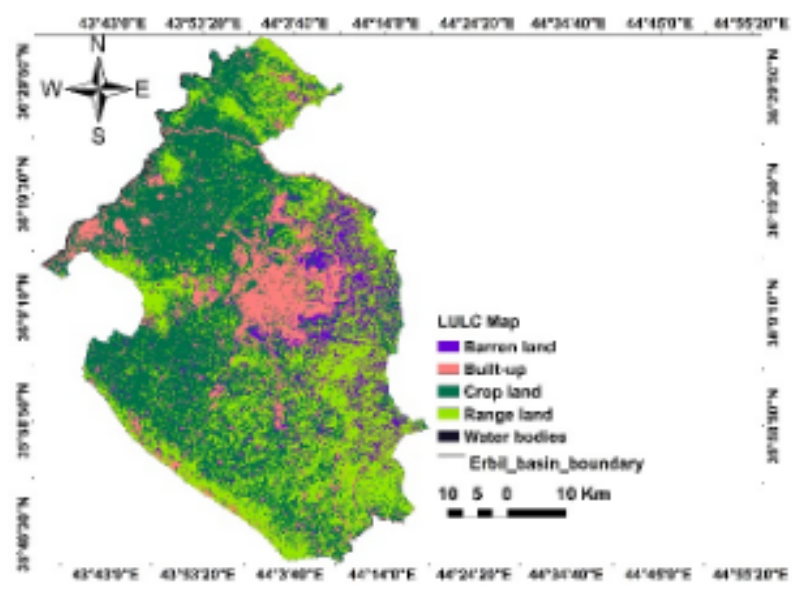

d

Figure 3 
(a) Average rainfall map, (b) Geological map, (c) Lithological map, (d) LULC map of the study area.

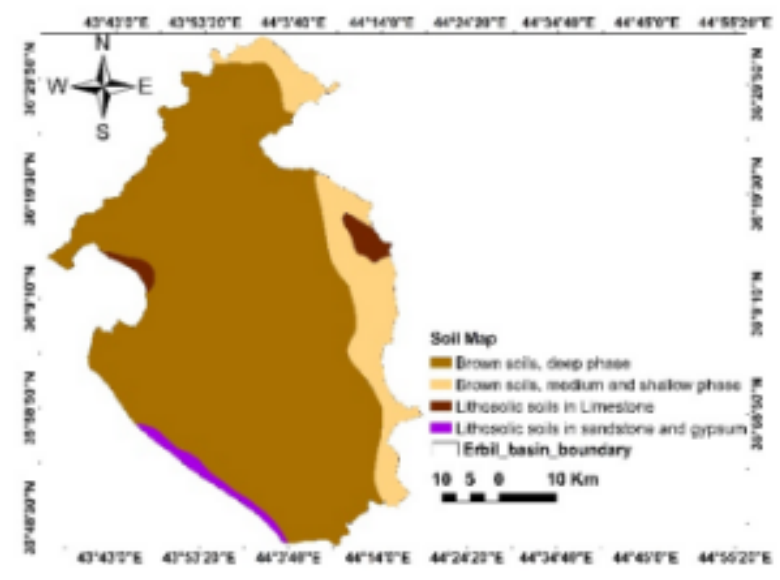

a

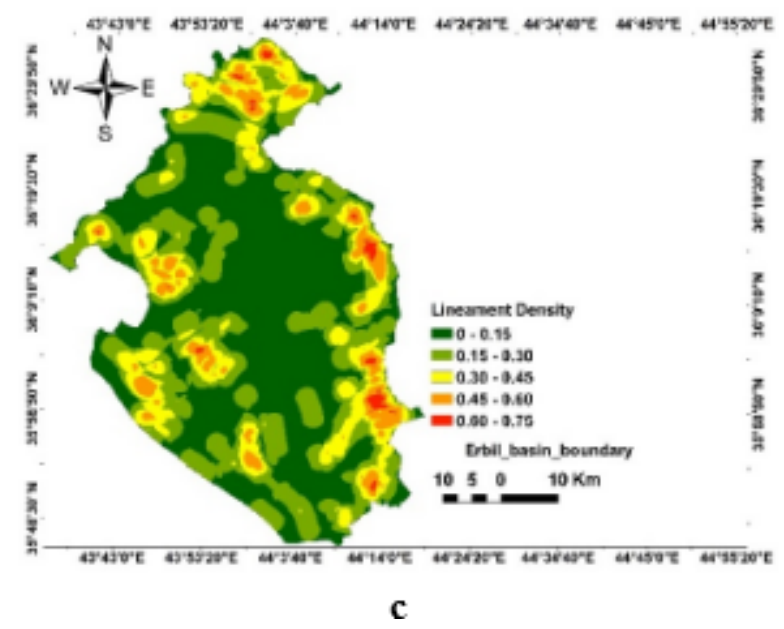

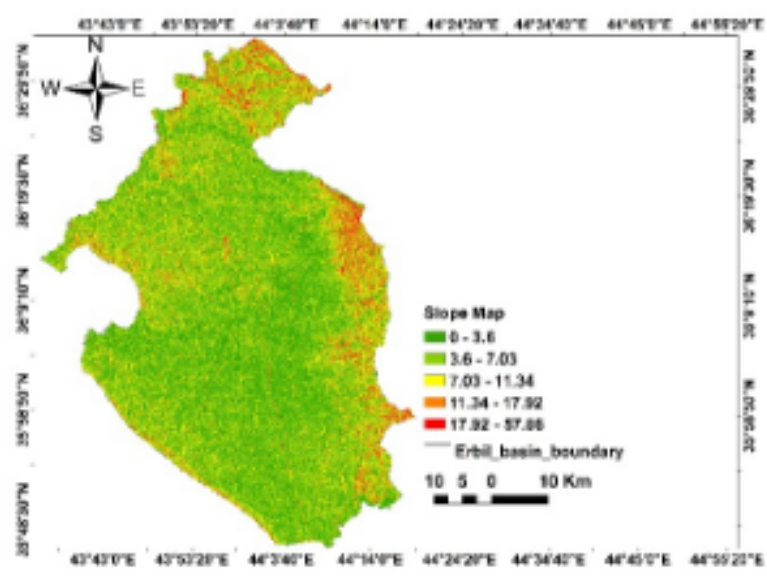

b

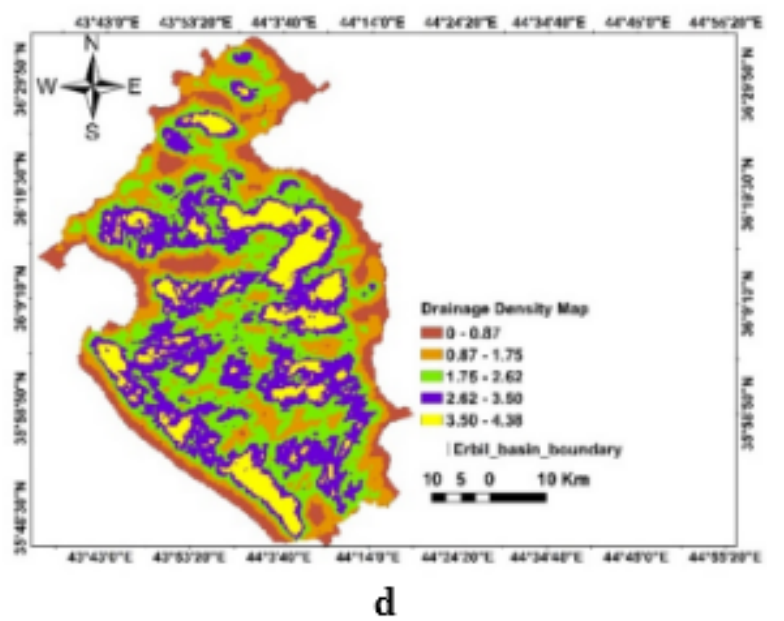

Figure 4

(a) Soil map, (b) Slope map, (c) Lineament density, (d) Drainage density of the study area 


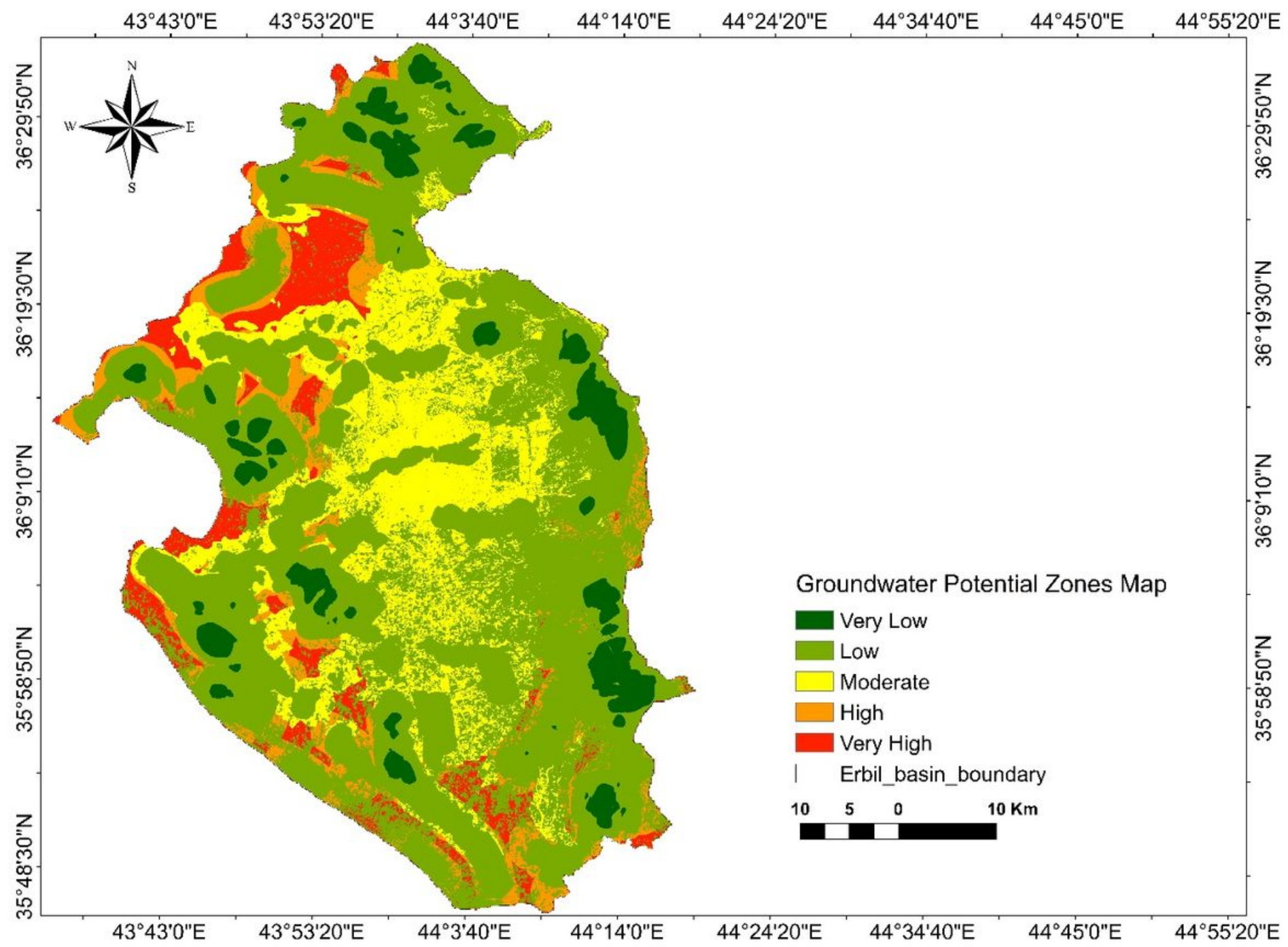

Figure 5

The groundwater potential zones map of the study area 


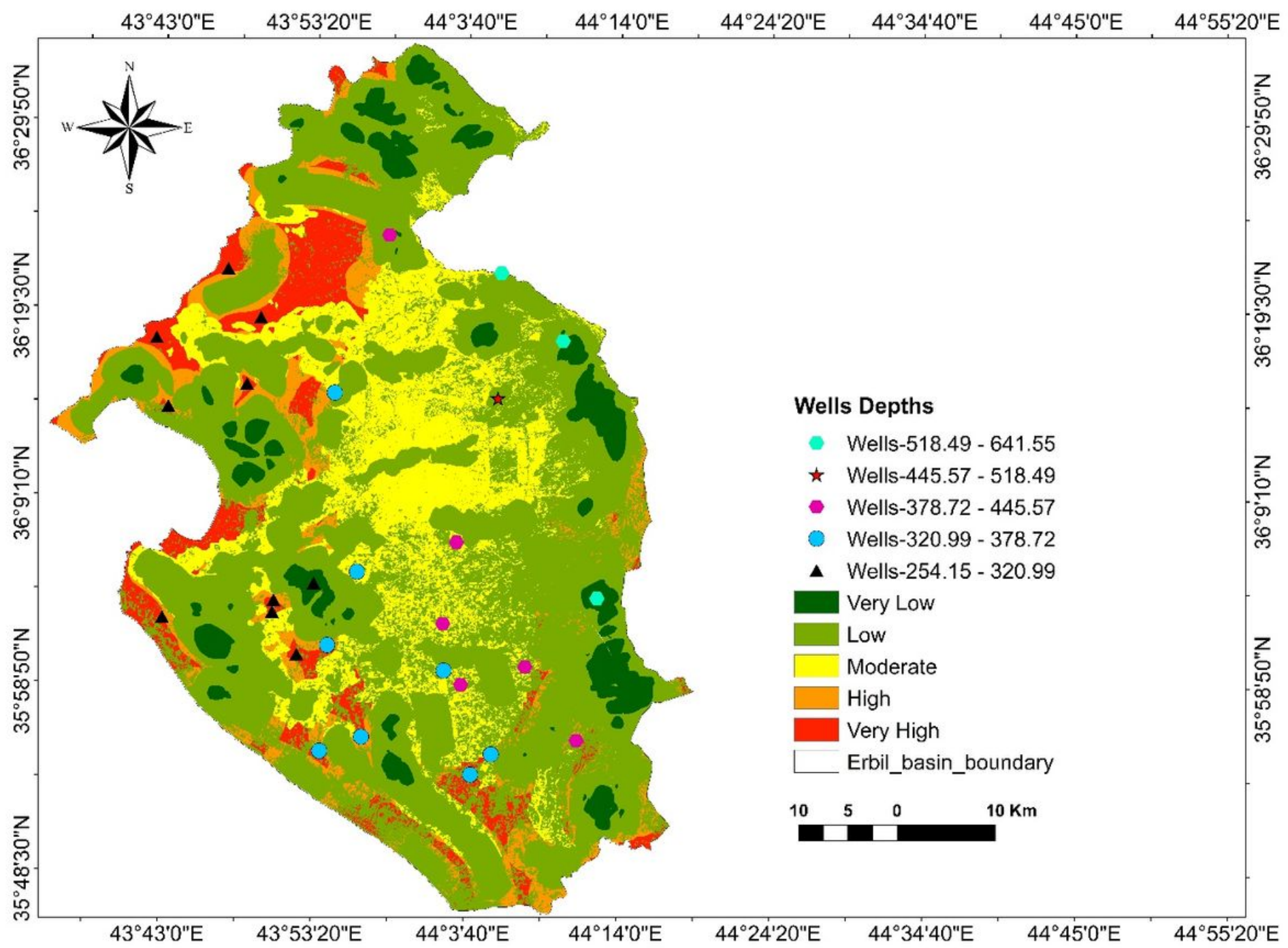

Figure 6

Groundwater potential zones map of the study area and model validation through the wells. 


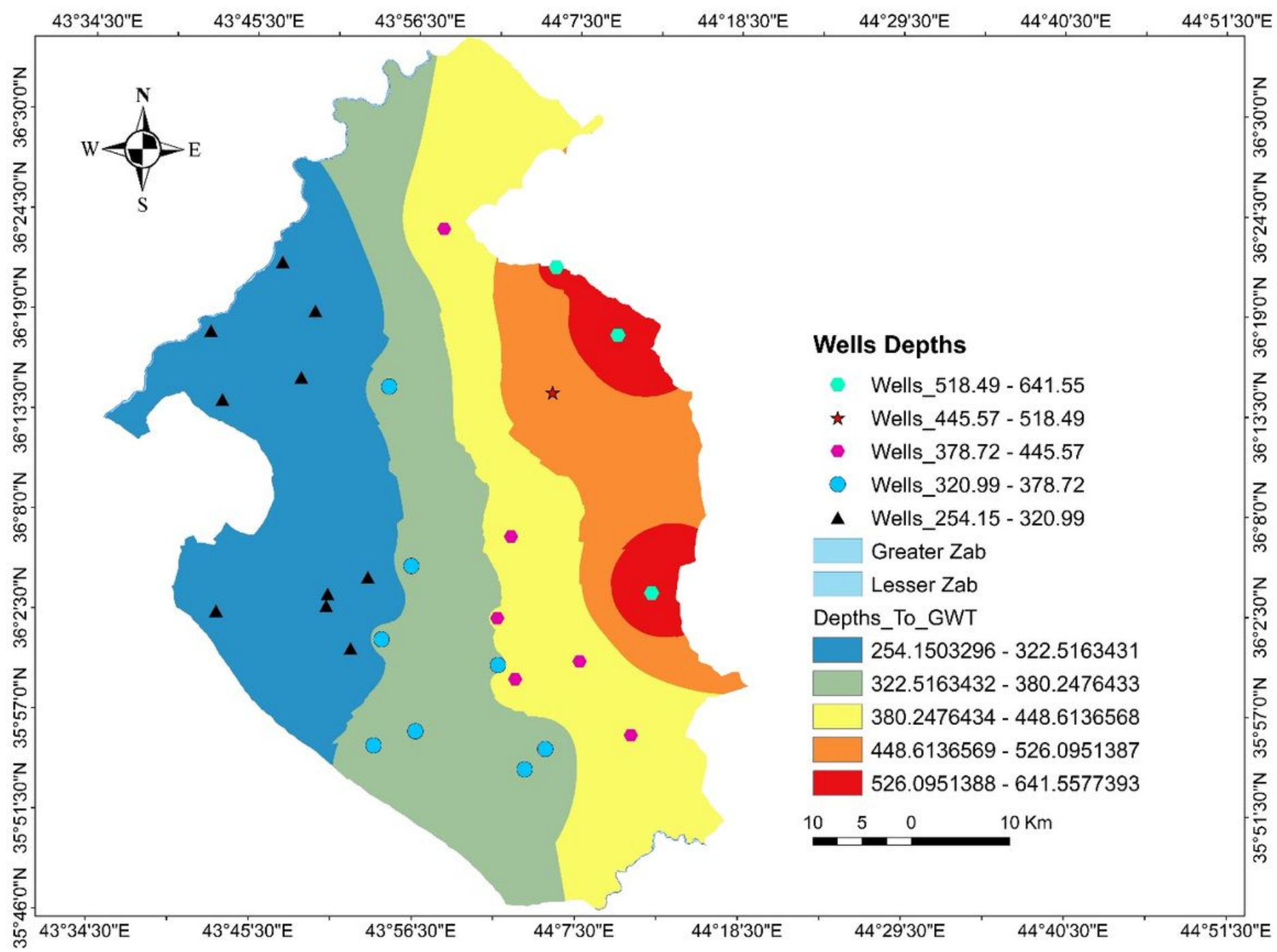

Figure 7

Groundwater level depths in Erbil basin 